\title{
ESPERANÇA E GRATIDÃO: A CIÊNCIA E TECNOLOGIA E OS AVANÇOS PARA A IMUNIZAÇÃO CONTRA O CORONAVÍRUS 19.
}

Novo ano e a esperança deve ser renovada. O ano de 2020 foi marcado pela pandemia do Coronavirus 19. Muitas mudanças, com adaptações, tiveram que ser adotadas, para que pudéssemos passar por esse período com maior segurança sem, entretanto, termos que deixar todas as nossas atividades, principalmente quando pensamos no ensino, na pesquisa e no atendimento à comunidade. A área da saúde foi a que mais enfrentou e vem enfrentando os maiores desafios, para poder minimizar a dor e o sofrimento dos pacientes acometidos, e de seus familiares. Efeitos devastadores para a economia nacional e mundial, e ainda estaremos por um longo período de tempo sofrendo as consequências dos efeitos da pandemia, que será inesquecível para todos nós, que estamos vivenciando de perto ou mesmo que mais distantes, o dia a dia da sua evolução, tendo que aceitar que o principal responsável pela situação catastrófica em que o mundo se encontra, é o próprio povo, que negligência todas as orientações das autoridades de saúde, que são transmitidas incansavelmente, quase que diuturnamente. Há abusos por parte da maioria, apesar de uma parcela consciente entender a importância da prática do distanciamento social, o uso de máscaras, da lavagem das mãos com água e sabão ou detergente, e do álcool em gel.

Os dados recentes divulgados da vacina CoronaVac, trazem alento pois a eficácia de $50,4 \%$, não quer dizer que a vacina tem $50,0 \%$ de chance de dar errado. $\mathrm{Na}$ verdade, ao tomar a vacina, tem-se $50,4 \%$ de chances de não desenvolver COVID-19, 78\% de chances de não precisar de atendimento médico algum e $100 \%$ de chances de não precisar ser hospitalizado ou ir para a UTI. Importante em tudo isso é que deveremos continuar cumprindo a nossa parte enquanto cidadãos, res peitando as nossas próprias vidas, bem como a de nossos semelhantes. Teremos um bom tempo até que a grande maioria da população tenha sido vacinada e esteja de fato protegida, ou seja, imunizada, a partir da produção de anticorpos, em resposta às vacinas.

Caminhamos em 2021, com muitas dúvidas, e expectativas, de dias melhores. Foram tempos difíceis, onde as palavras-chave foram "alcool em gel" e "distanciamento social". Foram diagnosticadas várias cepas e a preocupação e o medo foram constantes. A ciência superou obstáculos e está vencendo barreiras, com expectativas positivas para o controle desta terrível pandemia.

Estamos fechando o volume do ano de 2021, da revista Veterinária e Zootecnia, $\mathrm{N}^{\mathrm{o}} 28$, editorado de forma contínua, de acordo com a liberação dos artigos após análise de mérito científico pela Assessoria, e também da normalização bibliográfica por equipe especializada. A submissão de artigos prossegue para o início do volume 
$\mathrm{N}^{\mathrm{o}} 29$, e convidamos a comunidade científica para submissão de artigos de acordo com as normas da Revista.

Aproveitamos para desejar Feliz Natal e venturoso 2022, agradecendo a todos que contribuíram para a formatação final e edição deste volume.

Boa leitura.

Professor Helio Langoni

Editor Chefe 